\section{RICHARD WOODMAN'S ECONOMIC RIVALS}

RICHARD WOODMAN, the Sussex iron master and Protestant martyr who was burnt at Lewes in 1557, left a detailed account of his capture and his six interrogations by the Sussex Marian authorities. Woodman's narrative is preserved in Foxe's Acts and Monuments and is the most in-depth account of the trials of any of the Sussex martyrs. Woodman's narrative, as it appears in Foxe, reveals a notable controversialist, well equipped to challenge his accusers; this is manifest in his complaint regarding the legality of anyone other than his ordinary questioning him on points of doctrine. ${ }^{1}$ The questionable recourse of the appointment of Nicholas Harpsfield as his ordinary suggests a desire to extinguish Woodman as a local focus for Protestantism. ${ }^{2}$ Woodman's surviving correspondence to a fellow Sussex Protestant indicates his importance to the embattled Reformed population of eastern Sussex, ${ }^{3}$ while his detailed interrogations demonstrates someone clearly at odds with restored Catholic doctrine and unwilling to compromise with the Marian authorities.

However, Woodman's narrative also suggests a second reason why his removal from Sussex society might have been welcomed by his opponents - economic rivalry. Woodman is explicit as to the financial motive behind the exposure of his hiding place to the Sussex authorities, a revelation which resulted in his second and final arrest in 1557. Having evaded capture by fleeing to France for three weeks before returning to Sussex, and then by hiding in the woods near his home and in a hiding space in his house, Woodman was finally captured after his location was revealed by his brother. Woodman was in dispute with his brother and father regarding goods which they were holding on his behalf. Having instructed that the goods be used to pay his

\footnotetext{
1 John Foxe, The Unabridged Acts and Monuments Online or TAMO TAMO (1570 edition) (Sheffield, 2011). Available from: $<$ http $/ /$ www.johnfoxe.org $>$, last accessed 26 August 2014.

2 Foxe, TAMO (1570 edition) (Sheffield, 2011); see also Thomas S. Freeman, 'Woodman, Richard', ODNB (2004) online edition, last accessed 26 August 2014.

3 Woodman's letter to Mrs Roberts is affixed to his narrative in Acts and Monuments from the 1570 edition onwards.
}

debts, Woodman's brother and father refused, claiming the goods would not cover the debt. Woodman rejected this claim; the narrative of his capture claims the goods were worth $£ 200$ more than the debt. Having arranged to come to a reckoning regarding his property and debts, Woodman was promptly arrested having been surprised at his home by Sir Edward Gage's men. Woodman blamed his brother for his arrest, accusing him of revealing Woodman's location in order to maintain his possession of Woodman's goods. ${ }^{4}$ There is thus a clear correlation between Woodman's second arrest and the financial motivations of others.

This financial consideration can be extended to include a number of those involved in Woodman's six interrogations. Woodman's employment of one hundred workers, ${ }^{5}$ and the claim that his goods outweighed his debts by $£ 200$, suggests that he was a considerable figure within the Wealden iron industry. It is therefore suggestive that several of those present or engaged in Woodman's examinations were directly concerned with the Wealden iron industry or can be demonstrated to have links with the iron trade via a large, interconnected group of powerful Catholic families who dominated Sussex politics during the period.

Although the records for the Wealden iron trade are incomplete - with the only surviving list from the Elizabethan period dating from $1574^{6}$ - the work of Henry Cleere and David Crossley enables us to speculate regarding the identities of those involved in the industry during the 1550s. The partial record for that period reveals that a number of the individuals involved in the prosecution of Woodman had a direct interest in the Sussex iron industry or can be convincingly demonstrated to have a close connection to individuals involved in the iron industry. This potential economic factor in the prosecution of Woodman can be observed in his arrests in both 1554 and 1557. In 1554, the Justices of the Peace for Sussex before whom Woodman

\footnotetext{
4 Foxe, TAMO (1570 edition) (Sheffield, 2011).

5 Freeman, 'Woodman, Richard', $O D N B$.

6 J. J. Goring, 'Wealden Ironmaster in the Age of Elizabeth' in E. W. Ives, R. J. Knecht, J. J. Scarisbrick (eds), Wealth and Power in Tudor England (London, 1978), 205.
} 
was presented included John Ashburnham and 'M. Culpepper'. J John Ashburnham operated the furnace at Ashburnham, near Penshurst. ${ }^{8}$ The Ashburnham family were involved in the iron industry from 1549 until the early nineteenth century. Culpepper has been identified by Michael Questier as Alexander Culpepper who married the sisterin-law of Anthony Browne, First Viscount Montague. ${ }^{9}$ The Culpepper family operated Bedgebury Furnace in $1574 ;{ }^{10}$ as the family owned Bedgebury from 1425 it is not unreasonable to assume that if the furnace was operational in 1554 then it was operated by, or on behalf of, the Culpepper family. Moreover, Thomas Culpepper (d. 1558) who owned the Postern forge and Vauxhall furnace in Tonbridge was almost certainly Alexander Culpepper's father. ${ }^{11}$ Two of Woodman's initial interrogators were, therefore, fellow members of the Wealden iron trade and potential economic rivals. They were also part of the network of Sussex's Catholic families whose de facto leaders were the Brownes and the Gages. These two dominant families played prominent roles in Woodman's 1557 interrogations and had multiple connections to the iron industry.

Sir Edward Gage was responsible for Woodman's final arrest; Woodman was held at the Gage house at Firle, and James Gage was present at Woodman's third examination. ${ }^{12}$ The Gage family had interests in the steel forge at Hartfield and the Stumbleths Furnace

\footnotetext{
7 Foxe, TAMO (1570 edition) (Sheffield, 2011).

${ }^{8}$ Henry Cleere and David Crossley, The Iron Industry of the Weald (Cardiff, 1995), 310-11.

${ }^{9}$ Michael Questier, Catholicism and Community in Early Modern England: Politics, Aristocratic Patronage and Religion, 1590 - 1640 (Cambridge, 2006), 163.

${ }^{10}$ Cleere and Crossley, The Iron Industry of the Weald, 314.

11 Thomas Culpepper and Sir George Harper were granted the right to build the Postern forge at Tonbridge in 1553, see Cleere and Crossley, The Iron Industry of the Weald, 352; The Vauxhall furnace was operated by Northumberland in 1552 and was leased to Harper and Culpepper at the end of 1552 who were given permission to build another forge and furnace, see Cleere and Crossley, The Iron Industry of the Weald, 362. The Culpeppers owned the rectory of Tonbridge and its appurtances by 1555 . The property included land called the Postern which may indicate the location of the forge, see $<$ http://gen.culpepper.com/archives/uk/places/tonbridge.htm >, accessed 29 August 2014.

${ }^{12}$ Foxe, TAMO (1570 edition) (Sheffield, 2011).
}

at Marefield in 1554, although these were transferred to the Crown in $1554 .{ }^{13}$ The Gages were cousins of the Brownes-Alice Gage was the grandmother of Anthony Browne, First Viscount Montague. ${ }^{14}$ The Brownes were involved in the iron industry through their ownership of the Bayham forge at Lamberhurst; it was their property until 1609 although it was tenanted by William Wybarne in the $1520 .{ }^{15}$ Woodman's third examination took place in the Brownes' house at Southwark while the fifth examination took place in St Mary Ovaries, the Brownes' parish church in Southwark. Alban Langdale, the future chaplain of Viscount Montague and 'Montague's agent in the Marian attempt to extirpate heresy from Sussex ${ }^{16}{ }^{16}$ was present at Woodman's third, fifth, and six examinations in 1557. Although Langdale had a national significance - having played a role in the Oxford debates - his part in the interrogation of Woodman highlights the role of the Browne family and their wider Sussex network in Woodman's prosecution.

The Brownes and the Gages had further interests in the Wealden iron industry through their wider network. The Pelham family were prominent in the trade and can be connected to the Brownes and Gages through their connections to the Darrells. Thomas Darrell of Scotney was a servant of Sir John Gage and was Sir Anthony Browne's understeward $;{ }^{17}$ the Darrells would eventually forge a martial connection with the Gages through the union of Henry Darrell to Margaret Gage, the daughter of Sir Edward Gage. A branch of the Darrell family owned the Ewood forge and furnace until 1554 when Anthony Pelham bought the interest in the operation. ${ }^{18}$ Anthony Pelham was the uncle of Sir Edmond (or Edmund) Pelham; Edmond Pelham was part of Magdalene Browne's circle at Battle later in

\footnotetext{
13 Cleere and Crossley, The Iron Industry of the Weald 358-9.

${ }^{14}$ Questier, Catholicism and Community, appendix 2, unpaginated.

${ }_{15}$ Cleere and Crossley, The Iron Industry of the Weald, 313. Wybarne was operating Breeches forge in Frant in 1544, see The Iron Industry of the Weald, 318.

${ }_{16}$ Questier, Catholicism and Community, 163.

${ }_{17}$ Questier, Catholicism and Community, 104.

18 Cleere and Crossley, The Iron Industry of the Weald, 331.
} 
the century, ${ }^{19}$ and his wife was one of the Scotney Darrells. ${ }^{20}$ The Pelhams also owned Bibleham forge and Crowhurst forge and furnace, the former possibly from 1550 and the latter certainly in $1544 .^{21}$ The Pelhams may also have held the Hendall furnace at Buxted. $^{22}$

The Pelham/Darrell/Browne/Gage iron interest can be extended if the Cowbeach/ Cralle furnace and forge in Warbleton is included in the present consideration. The Cowbeach/Cralle works probably belonged to the Cheney family. ${ }^{23}$ Cralle Manor had been part of the Cheney estates since the marriage of Richard Cheney to Margaret de Cralle in the latter half of the fifteenth century; if the Cralle iron works were operational in 1557 then it seems probable that the Cheneys were in charge. Pelham Cheney owned an iron mill at Badhurst Manor at his death in $1559,{ }^{24}$ thus indicating a family connection to the trade. The Cheneys were cousins of the Scotney Darrells and Pelham Cheney's first name perhaps indicates a familial relationship with the Pelhams. The Cowbeach/Cralle works at Warbleton are particularly significant as Woodman's forge or furnace was also at Warbleton. This leads to the distinct possibility that the closest rival works to Woodman's own was operated by a family who had blood ties to the Catholic network responsible for Woodman's arrest and which had an interest in at least eleven forges and furnaces in eastern Sussex. That leaves the possibility that Woodman's prosecution and execution may

${ }^{19}$ See Questier, Catholicism and Community, 221-2; see also Lansdone MS 82, no, 49, sig. 103 r-v.

${ }^{20}$ Questier, Catholicism and Community, 78.

21 Cleere and Crossley, The Iron Industry of the Weald, 316, 326-7. The 'alien list' of foreigner workers complied in 1544 provides invaluable evidence for the existence of Wealden forges and furnace. The Hendall furnace at Buxted, which is listed on the alien list, was possibly operated by a member of the Pelham family. Anthony Pelham was from Buxted.

${ }^{22}$ Cleere and Crossley, The Iron Industry of the Weald, 335-6. The furnace and the Pelhams ownership of it are listed on the 1544 'alien list' but the position of the furnace in 1557 remains unclear. Sir Nicholas Pelham owned the Penshurst furnace (349-50); Sir Nicholas was from the Protestant branch of the family.

${ }^{23}$ Cleere and Crossley, The Iron industry of the Weald, 324.

${ }^{24}$ Cleere and Crossley, The Iron industry of the Weald, 324. well have been welcomed for economic reasons as well as on doctrinal grounds.

University of Sussex

PAul QuinN

doi:10.1093/notesj/gju260

(C) The Author (2015). Published by Oxford University Press.

All rights reserved. For Permissions, please email: journals.permissions@oup.com Advance Access publication 6 February, 2015

\section{THOMAS CHURCHYARD AND MUSIC}

THOMAS CHURCHYARD had a life-long interest in music. In one of his perilously semi-autobiographical poems, the 'Storie translated out of Frenche', in which he presents a rather idealized version of childhood, he tells us that his youthful studies in language and grammar were complemented by instruction in music, and later in the same work refers to once owning a lute, albeit just before describing how he broke it in frustration at his miserable fortunes in love. ${ }^{1}$ When he recalls how he first presented himself at the court of Henry VIII during the 1540s he casts himself as much as a performer and entertainer as someone skilled solely in the verbal arts. As he writes in 'Churchyardes farewell from the Courte, the seconde yere of the Queenes Maiesties raigne':

I hapt in Courte (as newe Brome maie,

That sweepeth trimely for a daie.)

To be desierd to plaie and syng,

And was full glad in every thyng:

To please the Lordes, and lordely sorte,

For that ye knowe with chaunge of sporte.

These Courtiars humours should be fedde,

And glad I was to bende my hedde:

And be at becke when thei did call,

In hope that somme good happ would fall.

To me for that apt will of myne,

Although my doyngs were not fine:

A Tabber with a Pipe full loude,

To better noyse is but a cloude. ${ }^{2}$

It therefore comes as no surprise to see Churchyard regularly using musical conceits and analogies in his poetry, and - in his 1595 A Musicall Consort of Heavenly Harmonie (compounded out of manie partes of Musicke) called

\footnotetext{
1 Thomas Churchyard, Churchyardes Chance (London, 1580), sig. A4v.

2 Thomas Churchyard, Churchyardes Charge (London, 1580), sig. Clv.
} 